\title{
Parameters affecting oil extraction from rambutan (Nephelium lappaceum L.) seed
}

\author{
Nguyen Phuoc Minh \\ Institute of Applied Technology, Thu Dau Mot University, Binh Duong Province, Vietnam \\ *Email: nguyenphuocminh@tdmu.edu.vn
}

\section{ARTICLE HISTORY}

Received: 25 February 2021

Accepted: 18 July 2021

Available online: 18 September 2021

\section{KEYWORDS}

Antioxidant potential

Oxidative indicator

Recovery efficiency

Rambutan seed

Solvent extraction

Vegetable oil
ABSTRACT

Rambutan (Nephelium lappaceum L.) seed is commonly discarded as waste. This seed contains abundant fat that is a valuable source for vegetable oil production. To utilize this seed as a potential oil source for the human diet, this research investigated some technical variables in solvent extraction affecting the yield and quality of vegetable oil. The present research focused on the effect of particle seed size (48-28 mesh sieve), mixture of ethanol/ethyl acetate $(1 / 1,2 / 1,3 / 1,1 / 2,1 / 3)$, solvent to solid ratio $(5 / 1,6 / 1,7 / 1,8 / 1,9 / 1)$, extraction temperature $\left(40-60{ }^{\circ} \mathrm{C}\right)$ and extraction time $(30-90 \mathrm{~min})$. Results showed that rambutan seed should be finely ground to 35 mesh sieve, soaked with ethanol/ethyl acetate $(3 / 1, \mathrm{v} / \mathrm{v})$ for $30 \mathrm{~min}$, solvent/material ratio $(7 / 1, \mathrm{v} / \mathrm{w})$, extraction temperature $\left(50^{\circ} \mathrm{C}\right)$ in $60,75,90 \mathrm{~min}$ to obtain the high recovery efficiency $(95.70 \pm 0.01 \%)$ and medium antioxidant potential (total phenolic content: $14.97 \pm 0.01 \mathrm{mg} \mathrm{GAE} / \mathrm{g}$, total carotenoid content: $109.58 \pm 0.02 \mathrm{mg} / \mathrm{kg}$ ); the low percentage of inhibition to radical DPPH $(20.45 \pm 0.00 \mathrm{mg} / \mathrm{ml})$, low peroxide value $(1.49 \pm 0.03$ $\mathrm{mEq} / \mathrm{kg})$, acid value $(1.39 \pm 0.02 \mathrm{mg} \mathrm{KOH} / \mathrm{gm})$, iodine value $(18.27 \pm 0.00 \mathrm{gm} / 100 \mathrm{gm})$, saponification value (86.15 $\pm 0.03 \mathrm{mg} \mathrm{KOH} / \mathrm{gm}$ ). Comparing to TCVN 7597: 2013, the extracted rambutan seed oil had oxidative indicators within the acceptable limit. This rambutan seed oil would be a potential ingredient for cosmetic and personal health care industries.

\section{Introduction}

There has an increasing demand for vegetable oil from different plant sources (1). Solvent extraction is one of the most beneficial extraction methods widely used to collect vegetable oil from oilseeds with excellent recovery efficiency, consistent manipulation, and less residual oil remained in the cake $(2,4)$. However, solvent extraction also revealed disadvantages like extended extraction duration, relatively high solvent involvement, high investment, labour and energy consumption, fire issue, the release of volatile organic substances, low product quality and complicated handling steps $(5,6)$. The main obstacles related to the solvent extraction method are extraction duration lag and adverse thermal effects at high temperatures (7). The solvent selection relies on the optimal leaching attributes of the required solute substrate (8). Hexane, diethyl ether, petroleum ether and ethanol are universal solvents used for oil extraction. Excellent solvent-solute ratio, the relative volatility of solvent to oil, oil viscosity and polarity, price and accessibility are important indicators in choosing solvent $(6,9)$.
Rambutan seed is normally considered waste during fruit processing. Its seed occupies about $4.0-9.5 \%$ of the total weight of whole fruit (10). The dried seed contains abundant protein, lipid and carbohydrates (11). The amount of oil (14-41\%) with high oleic acid renders the seed a potential source of vegetable oil (12). The main fatty acids include palmitic acid, stearic acid, oleic acid and arachidic acid (13). It can be roasted into instant snack food (14). Rambutan seed oil could be substituted with cocoa butter to produce the functional similarity of the cocoa butter in confectionery (15-17). Rambutan seed oil could be a potential carrier for fat-soluble vitamins (18). Apart from food utlilization, rambutan seed could be exploited for multiple applications such as bio-coagulant, personal care, bio-sorbent, biomedical, biodiesel and packaging to aleviate overload of rambutan by-products during processing (12). The main objective of our study was to verify major technical parameters such as seed powder size, the mixture of ethanol/ethyl acetate, solvent to solid ratio, extraction temperature and extraction time in solvent extraction affecting yield and quality of vegetable oil.

(c) Minh (2021). This is an open-access article distributed under the terms of the Creative Commons Attribution License, which permits unrestricted use, distribution and reproduction in any medium, provided the original author and source are credited (https://creativecommons.org/licenses/by/4.0/) 


\section{Materials and Methods}

\section{Material}

Rambutan seed was collected from Soc Trang province, Vietnam. The raw seed was dried under sunlight for three consecutive days to the final moisture content of 9-9.5\%. It was kept at room temperature, ready for oil extraction. Ethanol, ethyl acetate, glacial acetic acid, cyclohexane, potassium iodide, sodium thiosulfate and other chemical reagents were all analytical grade (> $99 \%$ in purity) purchased from Sigma-Aldrich, Merck, Systerm was utilized during experiments.

\section{Experiments}

\section{Experiment 1}

Effect of seed powder size on recovery efficiency and antioxidant stability of the oil. Seed was finely ground into various sizes $(48,42,35,32,28$ mesh sieve). Seed powder was soaked with ethanol/ethyl acetate $(1: 1, \mathrm{v} / \mathrm{v})$ for $30 \mathrm{~min}$, solvent/material ratio (5/1), extraction temperature $40{ }^{\circ} \mathrm{C}$ in $45 \mathrm{~min}$ in Erlenmeyer flasks placed in a horizontal incubator shaker (New Brunswick ${ }^{\mathrm{TM}}$ Innova ${ }^{\circledR} 2350$ ) at $120 \mathrm{rpm}$ to obtain crude oil. It was then filtered through Whatman paper No. 4 under vacuum pressure to get edible oil.

\section{Experiment 2}

Effect of solvent on recovery efficiency and antioxidant stability of the oil. The seed was finely ground to 35 mesh sieve. Seed powder was soaked with different solvent mixtures of ethanol/ethyl acetate $(1 / 1,2 / 1,3 / 1,1 / 2,1 / 3, v / v)$ for 30 minutes, solvent/material ratio (5/1), extraction temperature $40{ }^{\circ} \mathrm{C}$ in $45 \mathrm{~min}$ in Erlenmeyer flasks placed in a horizontal incubator shaker (New Brunswick ${ }^{\mathrm{TM}}$ Innova ${ }^{\circledR} 2350$ ) at $120 \mathrm{rpm}$ to obtain crude oil. It was then filtered through Whatman paper No. 4 under vacuum pressure to get edible oil.

\section{Experiment 3}

Effect of solvent/material ratio on recovery efficiency and antioxidant stability of the oil. The seed was finely ground to 35 mesh sieve. Seed powder was soaked with ethanol/ethyl acetate $(3 / 1, \mathrm{v} / \mathrm{v})$ for 30 min, different solvent/material ratios $(5 / 1,6 / 1,7 / 1$, $8 / 1,9 / 1, \mathrm{v} / \mathrm{w}$ ), extraction temperature $40{ }^{\circ} \mathrm{C}$ for $45 \mathrm{~min}$ in Erlenmeyer flasks placed in a horizontal incubator shaker (New Brunswick ${ }^{\mathrm{TM}}$ Innova ${ }^{\circledR} 2350$ ) at $120 \mathrm{rpm}$ to obtain crude oil. It was then filtered through Whatman paper No. 4 under vacuum pressure to get edible oil.

\section{Experiment 4}

Effect of extraction temperature on recovery efficiency and antioxidant stability of the oil. The seed was finely ground to 35 mesh sieve. Seed powder was soaked with ethanol/ethyl acetate $(3 / 1, \mathrm{v} /$ v) for $30 \mathrm{~min}$, solvent/material ratio $(7 / 1, \mathrm{v} / \mathrm{w})$, extraction temperature $\left(40,45,50,55,60^{\circ} \mathrm{C}\right)$ for 45 min in Erlenmeyer flasks placed in a horizontal incubator shaker (New Brunswick ${ }^{\mathrm{TM}}$ Innova ${ }^{\circledR} 2350$ ) at $120 \mathrm{rpm}$ to obtain crude oil. It was then filtered through Whatman paper No. 4 under vacuum pressure to get edible oil.

\section{Experiment 5}

Effect of extraction time on recovery efficiency and antioxidant stability of the oil. The seed was finely ground to 35 mesh sieve. Seed powder was soaked with ethanol/ethyl acetate $(3 / 1, \mathrm{v} / \mathrm{v})$ for $30 \mathrm{~min}$, solvent/material ratio $(7 / 1, \mathrm{v} / \mathrm{w})$, extraction temperature $\left(45^{\circ} \mathrm{C}\right)$ for different durations $(30,45,60$, $75,90 \mathrm{~min})$ in Erlenmeyer flasks placed in a horizontal incubator shaker (New Brunswick ${ }^{\mathrm{TM}}$ Innova ${ }^{\circledR} 2350$ ) at $120 \mathrm{rpm}$ to obtain crude oil. It was then filtered through Whatman paper No. 4 under vacuum pressure to get edible oil.

The target functions in above experiment were evaluated in respect of recovery efficiency (\%), peroxide value $(\mathrm{mEq} / \mathrm{kg})$, acid value $(\mathrm{mg} \mathrm{KOH} / \mathrm{gm})$, iodine value $(\mathrm{gm} / 100 \mathrm{gm})$, saponification value (mg $\mathrm{KOH} / \mathrm{gm}$ ), total phenolic content (mg GAE/gm), total carotenoid (mg/kg), antioxidant activity expressed by inhibition $50 \%$ concentration or $\mathrm{IC}_{50}$ index $(\mathrm{mg} / \mathrm{ml})$.

\section{Physicochemical evaluation}

Oil recovery efficiency (\%) was calculated by comparing the oil content obtained in the extraction and the oil content in the seeds. Peroxide value (mEq/ $\mathrm{kg}$ ), acid value (mg $\mathrm{KOH} / \mathrm{gm})$, iodine value (gm/100 $\mathrm{gm})$, saponification value (mg $\mathrm{KOH} / \mathrm{gm})$ were evaluated by Soxhlet apparatus following standard methods expressed as the number of milligrams of potassium hydroxide $(\mathrm{KOH})$ required to saponify 1 gram of the test sample. Total phenolic content (mg GAE/gm) was estimated by Folin-Ciocalteu reagent assay (19). Total carotenoid (mg/kg) was determined by UV/Visible spectrophotometry (Shimadzu, model 160A, Kyoto, Japan) (20). $\mathrm{IC}_{50}$ index (mg/ml) was identified by the percentage of inhibition to radical DPPH of one sample solution concentration (21).

\section{Statistical summary}

The demonstrations were prepared as three replicates for different sample groups. The values were expressed as mean \pm standard deviation. The statistical summary was performed using Statgraphics version XVI.

\section{Results and Discussion}

\section{Effect of seed powder size to recovery efficiency and antioxidant stability of oil}

The effect of seed powder size on recovery efficiency and antioxidant stability of oil was presented in Table 1. In the range of $48-28$ mesh sieve of the particle powder, target functions of the recovery efficiency $(42.44 \pm 0.10$ to $67.78 \pm 0.09 \%)$, peroxide value $(3.79 \pm 0.03$ to $6.17 \pm 0.04 \mathrm{mEq} / \mathrm{kg})$, acid value $(3.06 \pm 0.04$ to $5.01 \pm 0.00 \mathrm{mg} \mathrm{KOH} / \mathrm{gm})$, iodine value $(35.79 \pm 0.02$ to $62.43 \pm 0.01 \mathrm{gm} / 100 \mathrm{gm}), \quad$ saponification value (158.16 \pm 0.01 to $197.56 \pm 0.03 \mathrm{mg} \mathrm{KOH} / \mathrm{gm})$, total phenolic content $(2.59 \pm 0.04$ to $3.76 \pm 0.00 \mathrm{mg} \mathrm{GAE} / \mathrm{gm})$, total carotenoid content $(42.36 \pm 0.02$ to $70.26 \pm 0.01 \mathrm{mg} /$ $\mathrm{kg}), \mathrm{IC}_{50}$ index $(51.83 \pm 0.00$ to $74.30 \pm 0.01 \mathrm{mg} / \mathrm{ml})$ were noticed. At the seed powder size 35 mesh sieve, the oil had the highest recovery $(67.48 \pm 0.09 \%)$ and antioxidant potential $(3.76 \pm 0.00 \mathrm{mg} \mathrm{GAE} / \mathrm{gm})$, the lowest percentage of inhibition to radical DPPH 
Table 1. Effect of seed powder size to recovery efficiency and antioxidant stability of oil

\begin{tabular}{lccccc}
\hline Seed powder size (mesh sieve) & $\mathbf{4 8}$ & $\mathbf{4 2}$ & $\mathbf{3 5}$ & $\mathbf{3 2}$ & $\mathbf{2 8}$ \\
\hline Recovery efficiency (\%) & $50.75 \pm 0.12^{\mathrm{bc}}$ & $63.07 \pm 0.07^{\mathrm{ab}}$ & $67.48 \pm 0.09^{\mathrm{a}}$ & $58.31 \pm 0.14^{\mathrm{b}}$ & $42.44 \pm 0.10^{\mathrm{c}}$ \\
\hline Peroxide value (mEq/kg) & $5.40 \pm 0.05^{\mathrm{ab}}$ & $4.22 \pm 0.01^{\mathrm{bc}}$ & $3.79 \pm 0.03^{\mathrm{c}}$ & $4.91 \pm 0.02^{\mathrm{b}}$ & $6.17 \pm 0.04^{\mathrm{a}}$ \\
\hline Acid value $(\mathrm{mg} \mathrm{KOH} / \mathrm{g})$ & $4.64 \pm 0.02^{\mathrm{ab}}$ & $3.75 \pm 0.03^{\mathrm{bc}}$ & $3.06 \pm 0.04^{\mathrm{c}}$ & $4.13 \pm 0.01^{\mathrm{b}}$ & $5.01 \pm 0.00^{\mathrm{a}}$ \\
\hline Iodine value $(\mathrm{g} / 100 \mathrm{~g})$ & $58.71 \pm 0.01^{\mathrm{ab}}$ & $41.63 \pm 0.00^{\mathrm{bc}}$ & $35.79 \pm 0.02^{\mathrm{c}}$ & $50.37 \pm 0.02^{\mathrm{b}}$ & $62.43 \pm 0.01^{\mathrm{a}}$ \\
\hline Saponification value $(\mathrm{mg} \mathrm{KOH} / \mathrm{g})$ & $181.35 \pm 0.00^{\mathrm{ab}}$ & $167.84 \pm 0.02^{\mathrm{bc}}$ & $158.16 \pm 0.01^{\mathrm{c}}$ & $174.24 \pm 0.00^{\mathrm{b}}$ & $197.56 \pm 0.03^{\mathrm{a}}$ \\
\hline Total phenolic $(\mathrm{mg} \mathrm{GAE} / \mathrm{g})$ & $2.71 \pm 0.03^{\mathrm{bc}}$ & $3.15 \pm 0.01^{\mathrm{ab}}$ & $3.76 \pm 0.00^{\mathrm{a}}$ & $2.86 \pm 0.02^{\mathrm{b}}$ & $2.59 \pm 0.04^{\mathrm{c}}$ \\
\hline Total carotenoid $(\mathrm{mg} / \mathrm{kg})$ & $50.49 \pm 0.00^{\mathrm{bc}}$ & $64.15 \pm 0.02^{\mathrm{ab}}$ & $70.26 \pm 0.01^{\mathrm{a}}$ & $57.83 \pm 0.03^{\mathrm{b}}$ & $42.36 \pm 0.02^{\mathrm{c}}$ \\
\hline $\mathrm{IC}_{50}$ index $(\mathrm{mg} / \mathrm{ml})$ & $69.85 \pm 0.03^{\mathrm{ab}}$ & $59.34 \pm 0.01^{\mathrm{bc}}$ & $51.83 \pm 0.00^{\mathrm{c}}$ & $64.07 \pm 0.02^{\mathrm{b}}$ & $74.30 \pm 0.01^{\mathrm{a}}$ \\
\hline
\end{tabular}

Figures are the mean of three replications; Figures in row followed by the same letter/s are not differed significantly $(\alpha=P=0.05)$.

$(51.83 \pm 0.00 \mathrm{mg} / \mathrm{ml})$. Therefore the seed powder size of 35 mesh sieve was selected for the next experiments. Large powder sizes ( 32 and 28 mesh sieve) limited the extraction rate and decreased the oil recovery efficiency receivable within a short extraction duration. However, too small particle size (48 and 35 mesh) also encountered limitation of oil extraction capacity due to fouling effect. The large surface area could explain this behaviour accounted for by the small particle-sized powder (22). Small particle size facilitated the accessibility of the soluble substrates located inside the sample matrix (23). The yield extraction of oleoresin extracted from ginger powder was obtained much more by small particle size, especially below 250 microns $(24,25)$. Coarse particle size $(0.5-0.75 \mathrm{~mm})$ was ideal for oil extraction from Jatropha seed (26). The optimal flake thickness for extraction of sunflower cotton and soybean seeds was noticed at 2-3 mm (27). A particle size of $2 \mathrm{~mm}$ was adequate for the solvent extraction of soybean oil (28). The particle size of the olive cake had a great influence on oil recovery efficiency. Decreasing the particle size of the olive cake significantly improved oil yield (29). A high percentage oil yield was found at $125 \mu \mathrm{m}$. Particle size affected the mass transfer kinetics and facilitated solvent into the soluble components. It directly influenced the extraction potential, diffusion gradient and extractability (30). Fine particles lowered the transmission of charge in the solute mass transfer rate (31). The diffusion way for the substance inside the particle was shorter hence supporting the extraction to be more simple and quickly (32).

\section{Influence of solvent on recovery efficiency and antioxidant stability of oil}

The solvent oil extraction is quite popular to mechanical press due to its excellent oil quality with limited refining (33). The purpose of oil extraction from seed was to receive the highest recovery efficiency and the best oil quality attributes. Ethanol and ethyl acetate are friendly to the environment and highly appreciated by the food industry (34). The influence of solvent on recovery efficiency and antioxidant stability of oil was presented in Table 2 . Among ethanol/ethyl acetate $(1 / 1,2 / 1,3 / 1,1 / 2,1 / 3, v / v)$, target functions of the recovery efficiency $(60.32 \pm 0.04$ to $79.23 \pm 0.03$ $\%$ ), peroxide value $(2.15 \pm 0.02$ to $4.63 \pm 0.01 \mathrm{mEq} / \mathrm{kg})$, acid value $(2.02 \pm 0.00$ to $3.71 \pm 0.02 \mathrm{mg} \mathrm{KOH} / \mathrm{gm})$, iodine value $(23.59 \pm 0.01$ to $40.63 \pm 0.03 \mathrm{gm} / 100 \mathrm{gm})$, saponification value $(130.97 \pm 0.03$ to $163.74 \pm 0.01 \mathrm{mg}$ $\mathrm{KOH} / \mathrm{gm})$, total phenolic content $(3.09 \pm 0.00$ to
$6.57 \pm 0.02 \mathrm{mg} \mathrm{GAE} / \mathrm{gm})$, total carotenoid content $(66.40 \pm 0.03$ to $78.26 \pm 0.00 \mathrm{mg} / \mathrm{kg}), \quad \mathrm{IC}_{50}$ index $(40.03 \pm 0.03$ to $57.19 \pm 0.02 \mathrm{mg} / \mathrm{ml})$ were noticed. At the ethanol/ethyl acetate $3 / 1$, the oil had the highest recovery $(79.23 \pm 0.03 \%)$ and antioxidant potential $(6.57 \pm 0.02 \mathrm{mg} \mathrm{GAE} / \mathrm{gm})$, the lowest percentage of inhibition to radical DPPH $(40.03 \pm 0.03 \mathrm{mg} / \mathrm{ml})$. Therefore, this value was selected for the next experiments.

Ethyl acetate was not to be superior to ethanol (35). The extraction yield improved by ethanol involvement (24). Hexane was suitable for oil extraction from Jatropha seed (26). Hexane was recommended the for extraction of sunflower cotton and soybean seeds (27). Ethyl acetate with a solvent to the material ratio of $10 / 1$ at ambient temperature would be an alternative to hexane in the oil extraction from passion fruit seeds (36). The dielectric constant of solvent for oil extraction should be in the range 6-8 (37). Ethyl acetate had a dielectric constant of 6.02, appropriate to obtain high recovery efficiency. Meanwhile, ethanol had a dielectric constant of 25.3. Complex solvent revealed a better effect than single solvent.

\section{Impact of solvent/material ratio to recovery efficiency and antioxidant stability of oil}

The influence of solvent/material ratio on recovery efficiency and antioxidant stability of oil was presented in Table 3. In different ratios of solvent/ material (5/1, 6/1, 7/1, 8/1, 9/1, v/w), target functions of the recovery efficiency $(78.52 \pm 0.03$ to $84.32 \pm 0.01$ $\%$ ), peroxide value $(1.67 \pm 0.00$ to $2.48 \pm 0.00 \mathrm{mEq} / \mathrm{kg})$, acid value $(1.59 \pm 0.02$ to $2.21 \pm 0.01 \mathrm{mg} \mathrm{KOH} / \mathrm{gm})$, iodine value $(19.14 \pm 0.03$ to $25.87 \pm 0.02 \mathrm{~g} / 100 \mathrm{gm})$, saponification value $(104.53 \pm 0.01$ to $134.65 \pm 0.00 \mathrm{mg}$ $\mathrm{KOH} / \mathrm{gm})$, total phenolic content $(5.92 \pm 0.02$ to $8.69 \pm 0.00 \mathrm{mg}$ GAE$/ \mathrm{gm}$ ), total carotenoid content $(75.19 \pm 0.01$ to $89.40 \pm 0.03 \mathrm{mg} / \mathrm{kg}), \quad \mathrm{IC}_{50}$ index $(29.83 \pm 0.02$ to $42.15 \pm 0.03 \mathrm{mg} / \mathrm{ml})$ were noticed. At the solvent/material ratio $7 / 1$, the oil had the highest recovery $(84.32 \pm 0.01 \%)$ and antioxidant potential $(8.69 \pm 0.00 \mathrm{mg} \mathrm{GAE} / \mathrm{gm})$, the lowest percentage of inhibition to radical DPPH $(29.83 \pm 0.02 \mathrm{mg} / \mathrm{ml})$. Therefore this value was selected for the next experiments. Solvent/material of 6/1 was ideal for oil extraction from Jatropha seed (26). The optimal solvent to solid of $1 / 1$ was a benefit for extraction of sunflower cotton and soybean seeds (27). Solvent to solid ratio at 20/1 greatly influenced oil extraction from olive cake (29). 
Table 2. Effect of ethanol/ethyl acetate to recovery efficiency and antioxidant stability of oil

\begin{tabular}{|c|c|c|c|c|c|}
\hline Ethanol/ethyl acetate (v/v) & $1 / 1$ & $2 / 1$ & $3 / 1$ & $1 / 2$ & $1 / 3$ \\
\hline Recovery efficiency (\%) & $67.48 \pm 0.09^{\mathrm{bc}}$ & $75.11 \pm 0.04^{\mathrm{ab}}$ & $79.23 \pm 0.03^{\mathrm{a}}$ & $70.66 \pm 0.08^{b}$ & $60.32 \pm 0.04^{\mathrm{c}}$ \\
\hline Peroxide value (mEq/kg) & $3.79 \pm 0.03^{\mathrm{ab}}$ & $2.64 \pm 0.03^{\mathrm{bc}}$ & $2.15 \pm 0.02^{\mathrm{c}}$ & $3.10 \pm 0.03^{b}$ & $4.63 \pm 0.01^{\mathrm{a}}$ \\
\hline Acid value (mg KOH/g) & $3.06 \pm 0.04^{\mathrm{ab}}$ & $2.30 \pm 0.01^{\mathrm{bc}}$ & $2.02 \pm 0.00^{c}$ & $2.81 \pm 0.04^{\mathrm{b}}$ & $3.71 \pm 0.02^{\mathrm{a}}$ \\
\hline Iodine value (g/100 g) & $35.79 \pm 0.02^{\mathrm{ab}}$ & $26.72 \pm 0.03^{\mathrm{bc}}$ & $23.59 \pm 0.01^{\mathrm{c}}$ & $31.08 \pm 0.03^{\mathrm{b}}$ & $40.63 \pm 0.03^{\mathrm{a}}$ \\
\hline Saponification value (mg KOH/g) & $158.16 \pm 0.01^{\mathrm{ab}}$ & $135.28 \pm 0.04^{\mathrm{bc}}$ & $130.97 \pm 0.03^{c}$ & $146.12 \pm 0.01^{\mathrm{b}}$ & $163.74 \pm 0.01^{\mathrm{a}}$ \\
\hline Total phenolic (mg GAE/g) & $3.76 \pm 0.00^{\mathrm{bc}}$ & $5.78 \pm 0.00^{\mathrm{ab}}$ & $6.57 \pm 0.02^{\mathrm{a}}$ & $4.42 \pm 0.00^{\mathrm{b}}$ & $3.09 \pm 0.00^{c}$ \\
\hline Total carotenoid (mg/kg) & $70.26 \pm 0.01^{\mathrm{bc}}$ & $76.40 \pm 0.01^{\mathrm{ab}}$ & $78.26 \pm 0.00^{\mathrm{a}}$ & $73.19 \pm 0.02^{\mathrm{b}}$ & $66.40 \pm 0.03^{c}$ \\
\hline $\mathrm{IC}_{50}$ index $(\mathrm{mg} / \mathrm{ml})$ & $51.83 \pm 0.00^{\mathrm{ab}}$ & $42.31 \pm 0.02^{\mathrm{bc}}$ & $40.03 \pm 0.03^{c}$ & $46.24 \pm 0.01^{\mathrm{b}}$ & $57.19 \pm 0.02^{\mathrm{a}}$ \\
\hline
\end{tabular}

Figures are the mean of three replications; Figures in row followed by the same letter/s are not differed significantly ( $\alpha=\mathrm{P}=0.05$ ).

Table 3. Effect of solvent/material ratio to recovery efficiency and antioxidant stability of oil

\begin{tabular}{|c|c|c|c|c|c|}
\hline Solvent/material ratio (v/w) & $5 / 1$ & $6 / 1$ & $7 / 1$ & $8 / 1$ & 9/1 \\
\hline Recovery efficiency (\%) & $79.23 \pm 0.03^{\mathrm{bc}}$ & $82.58 \pm 0.02^{\mathrm{ab}}$ & $84.32 \pm 0.01^{\mathrm{a}}$ & $81.33 \pm 0.05^{b}$ & $78.52 \pm 0.03^{\mathrm{c}}$ \\
\hline Peroxide value (mEq/kg) & $2.15 \pm 0.02^{\mathrm{ab}}$ & $1.83 \pm 0.01^{\mathrm{bc}}$ & $1.67 \pm 0.00^{c}$ & $1.95 \pm 0.02^{\mathrm{b}}$ & $2.48 \pm 0.00^{\mathrm{a}}$ \\
\hline Acid value (mg KOH/g) & $2.02 \pm 0.00^{\mathrm{ab}}$ & $1.75 \pm 0.03^{\mathrm{bc}}$ & $1.59 \pm 0.02^{c}$ & $1.87 \pm 0.00^{b}$ & $2.21 \pm 0.01^{\mathrm{a}}$ \\
\hline Iodine value (g/100 g) & $23.59 \pm 0.01^{\mathrm{ab}}$ & $20.36 \pm 0.02^{\mathrm{bc}}$ & $19.14 \pm 0.03^{\mathrm{c}}$ & $21.79 \pm 0.01^{\mathrm{b}}$ & $25.87 \pm 0.02^{\mathrm{a}}$ \\
\hline Saponification value (mg KOH/g) & $130.97 \pm 0.03^{\mathrm{ab}}$ & $111.38 \pm 0.01^{\mathrm{bc}}$ & $104.53 \pm 0.01^{\mathrm{c}}$ & $120.41 \pm 0.03^{b}$ & $134.65 \pm 0.00^{a}$ \\
\hline Total phenolic (mg GAE/g) & $6.57 \pm 0.02^{\mathrm{bc}}$ & $8.42 \pm 0.03^{\mathrm{ab}}$ & $8.69 \pm 0.00^{\mathrm{a}}$ & $7.67 \pm 0.01^{\mathrm{b}}$ & $5.92 \pm 0.02^{\mathrm{c}}$ \\
\hline Total carotenoid (mg/kg) & $78.26 \pm 0.00^{\mathrm{bc}}$ & $85.17 \pm 0.02^{\mathrm{ab}}$ & $89.40 \pm 0.03^{a}$ & $81.76 \pm 0.00^{\mathrm{b}}$ & $75.19 \pm 0.01^{\mathrm{c}}$ \\
\hline $\mathrm{IC}_{50}$ index $(\mathrm{mg} / \mathrm{ml})$ & $40.03 \pm 0.03^{\mathrm{ab}}$ & $32.49 \pm 0.01^{\text {bc }}$ & $29.83 \pm 0.02^{\mathrm{c}}$ & $36.27 \pm 0.00^{\mathrm{b}}$ & $42.15 \pm 0.03^{\mathrm{a}}$ \\
\hline
\end{tabular}

Figures are the mean of three replications; Figures in row followed by the same letter/s are not differed significantly $(\alpha=\mathrm{P}=0.05)$.

\section{Effect of extraction temperature to recovery efficiency and antioxidant stability of oil}

The influence of extraction temperature on recovery efficiency and antioxidant stability of oil was presented in Table 4. In different values of extraction decrease afterwards (38). Temperature supported the oil extraction; however, it should not be over the solvent's boiling point. Optimal temperature induced a breakdown of oil cells leading to lower oil viscosity, and numerous oil siphons permitted oil to escape

Table 4. Effect of extraction temperature to recovery efficiency and antioxidant stability of oil

\begin{tabular}{|c|c|c|c|c|c|}
\hline Extraction temperature $\left({ }^{\circ} \mathrm{C}\right)$ & 40 & 45 & 50 & 55 & 60 \\
\hline Recovery efficiency (\%) & $84.32 \pm 0.01^{\mathrm{bc}}$ & $87.43 \pm 0.03^{\mathrm{ab}}$ & $89.57 \pm 0.02^{\mathrm{a}}$ & $85.71 \pm 0.03^{b}$ & $82.37 \pm 0.00^{c}$ \\
\hline Peroxide value (mEq/kg) & $1.67 \pm 0.00^{\mathrm{ab}}$ & $1.41 \pm 0.02^{\mathrm{bc}}$ & $1.37 \pm 0.01^{\mathrm{c}}$ & $1.50 \pm 0.03^{\mathrm{b}}$ & $1.79 \pm 0.01^{\mathrm{a}}$ \\
\hline Acid value (mg KOH/g) & $1.59 \pm 0.02^{\mathrm{ab}}$ & $1.34 \pm 0.01^{\mathrm{bc}}$ & $1.28 \pm 0.03^{c}$ & $1.42 \pm 0.01^{\mathrm{b}}$ & $1.63 \pm 0.02^{\mathrm{a}}$ \\
\hline Iodine value (g/100 g) & $19.14 \pm 0.03^{\mathrm{ab}}$ & $15.68 \pm 0.00^{\mathrm{bc}}$ & $13.60 \pm 0.02^{\mathrm{c}}$ & $17.37 \pm 0.00^{b}$ & $21.15 \pm 0.00^{\mathrm{a}}$ \\
\hline Saponification value (mg KOH/g) & $104.53 \pm 0.01^{\mathrm{ab}}$ & $87.21 \pm 0.03^{\mathrm{bc}}$ & $80.32 \pm 0.00^{c}$ & $95.40 \pm 0.02^{\mathrm{b}}$ & $109.71 \pm 0.03^{\mathrm{a}}$ \\
\hline Total phenolic (mg GAE/g) & $8.69 \pm 0.00^{\mathrm{bc}}$ & $10.18 \pm 0.02^{\mathrm{ab}}$ & $10.53 \pm 0.03^{\mathrm{a}}$ & $9.41 \pm 0.01^{\mathrm{b}}$ & $8.01 \pm 0.03^{\mathrm{c}}$ \\
\hline Total carotenoid (mg/kg) & $89.40 \pm 0.03^{\mathrm{bc}}$ & $93.64 \pm 0.01^{\mathrm{ab}}$ & $97.35 \pm 0.01^{\mathrm{a}}$ & $91.38 \pm 0.03^{b}$ & $85.60 \pm 0.01^{\mathrm{c}}$ \\
\hline $\mathrm{IC}_{50}$ index $(\mathrm{mg} / \mathrm{ml})$ & $29.83 \pm 0.02^{\mathrm{ab}}$ & $25.40 \pm 0.03^{\mathrm{bc}}$ & $22.07 \pm 0.00^{c}$ & $27.14 \pm 0.02^{b}$ & $31.79 \pm 0.00^{\mathrm{a}}$ \\
\hline
\end{tabular}

Figures are the mean of three replications; Figures in row followed by the same letter/s are not differed significantly ( $\alpha=\mathrm{P}=0.05)$.

temperature $\left(40-60{ }^{\circ} \mathrm{C}\right)$, target functions of the recovery efficiency $(82.37 \pm 0.00$ to $89.57 \pm 0.02 \%)$, peroxide value $(1.37 \pm 0.01$ to $1.79 \pm 0.01 \mathrm{mEq} / \mathrm{kg})$, acid value $(1.28 \pm 0.03$ to $1.63 \pm 0.02 \mathrm{mg} \mathrm{KOH} / \mathrm{gm})$, iodine value $(13.60 \pm 0.02$ to $21.15 \pm 0.00 \mathrm{gm} / 100 \mathrm{gm})$, saponification value $(80.32 \pm 0.00$ to $109.71 \pm 0.03 \mathrm{mg}$ $\mathrm{KOH} / \mathrm{gm})$, total phenolic $(8.01 \pm 0.03$ to $10.53 \pm 0.03 \mathrm{mg}$ $\mathrm{GAE} / \mathrm{gm})$, total carotenoid $(85.60 \pm 0.01$ to $97.35 \pm 0.01$ $\mathrm{mg} / \mathrm{kg}), \mathrm{IC}_{50}$ index $(22.07 \pm 0.00$ to $31.79 \pm 0.00 \mathrm{mg} / \mathrm{ml})$ were noticed. At the extraction temperature $50{ }^{\circ} \mathrm{C}$, the oil had the highest recovery $(89.57 \pm 0.02 \%)$ and antioxidant potential $(10.53 \pm 0.03 \mathrm{mg} \mathrm{GAE} / \mathrm{gm})$, the lowest percentage of inhibition to radical DPPH $(22.07 \pm 0.00 \mathrm{mg} / \mathrm{ml})$. Therefore, this value was selected for the next experiments.

High temperatures $\left(>40^{\circ} \mathrm{C}\right)$ were recommended to obtain a high extraction yield (24). A temperature of $68{ }^{\circ} \mathrm{C}$ was ideal for oil extraction from Jatropha seed (26). The best extraction temperature for extraction of sunflower cotton and soybean seeds was noticed at $60-65^{\circ} \mathrm{C}(27)$. The temperature of $69^{\circ} \mathrm{C}$ was adequate for the solvent extraction of soybean oil (28). The oil recovery efficiency accelerated with the accumulated temperature to $90{ }^{\circ} \mathrm{C}$ and tended to easily $(27,39,40)$. With ethanol as solvent extraction, a significant isomerization was established in the hot temperature; however, oxidative decomposition was the predominant reaction. By ethyl acetate, the isomerization was the predominant one (4).

\section{Effect of extraction time to recovery efficiency and antioxidant stability of oil}

The influence of extraction time on recovery efficiency and antioxidant stability of oil was presented in Table 5. In different values of extraction duration (30-90 min), target functions of the recovery efficiency $(89.57 \pm 0.02$ to $96.01 \pm 0.03 \%)$, peroxide value $(1.37 \pm 0.01$ to $1.51 \pm 0.02 \mathrm{mEq} / \mathrm{kg})$, acid value $(1.28 \pm 0.03$ to $1.60 \pm 0.00 \mathrm{mg} \mathrm{KOH} / \mathrm{gm})$, iodine value $(13.60 \pm 0.02$ to $23.71 \pm 0.03 \mathrm{gm} / 100 \mathrm{gm})$, saponification value $(80.32 \pm 0.00$ to $90.64 \pm 0.01 \mathrm{mg} \mathrm{KOH} / \mathrm{gm})$, total phenolic ( $10.53 \pm 0.03$ to $17.85 \pm 0.02 \mathrm{mg} \mathrm{GAE} / \mathrm{gm})$, total carotenoid $(97.35 \pm 0.01$ to $121.43 \pm 0.00 \mathrm{mg} / \mathrm{kg}), \quad \mathrm{IC}_{50}$ index $(18.74 \pm 0.01$ to $22.07 \pm 0.00 \mathrm{mg} / \mathrm{ml})$ were noticed. The extraction time should be stopped at $60 \mathrm{~min}$ to obtain the high recovery efficiency $(95.70 \pm 0.01 \%)$ and medium antioxidant potential $(14.97 \pm 0.01 \mathrm{mg}$ GAE/gm), the low percentage of inhibition to radical DPPH $(20.45 \pm 0.00 \mathrm{mg} / \mathrm{ml})$. In another report, $8 \mathrm{hrs}$ of 
Table 5. Effect of extraction time to recovery efficiency and antioxidant stability of oil

\begin{tabular}{lccccc}
\hline Extraction duration (minutes) & $\mathbf{3 0}$ & $\mathbf{4 5}$ & $\mathbf{6 0}$ & 75 & $\mathbf{9 0}$ \\
\hline Recovery efficiency (\%) & $89.57 \pm 0.02^{\mathrm{b}}$ & $92.18 \pm 0.02^{\mathrm{ab}}$ & $95.70 \pm 0.01^{\mathrm{a}}$ & $95.91 \pm 0.02^{\mathrm{a}}$ & $96.01 \pm 0.03^{\mathrm{a}}$ \\
\hline Peroxide value $(\mathrm{mEq} / \mathrm{kg})$ & $1.37 \pm 0.01^{\mathrm{c}}$ & $1.42 \pm 0.00^{\mathrm{bc}}$ & $1.49 \pm 0.03^{\mathrm{b}}$ & $1.50 \pm 0.01^{\mathrm{ab}}$ & $1.51 \pm 0.02^{\mathrm{a}}$ \\
\hline Acid value $(\mathrm{mg} \mathrm{KOH} / \mathrm{g})$ & $1.28 \pm 0.03^{\mathrm{c}}$ & $1.33 \pm 0.04^{\mathrm{bc}}$ & $1.39 \pm 0.02^{\mathrm{b}}$ & $1.47 \pm 0.03^{\mathrm{ab}}$ & $1.60 \pm 0.00^{\mathrm{a}}$ \\
\hline Iodine value $(\mathrm{g} / 100 \mathrm{~g})$ & $13.60 \pm 0.02^{\mathrm{c}}$ & $16.38 \pm 0.01^{\mathrm{bc}}$ & $18.27 \pm 0.00^{\mathrm{b}}$ & $20.46 \pm 0.01^{\mathrm{ab}}$ & $23.71 \pm 0.03^{\mathrm{a}}$ \\
\hline Saponification value $(\mathrm{mg} \mathrm{KOH} / \mathrm{g})$ & $80.32 \pm 0.00^{\mathrm{c}}$ & $82.57 \pm 0.02^{\mathrm{bc}}$ & $86.15 \pm 0.03^{\mathrm{b}}$ & $89.12 \pm 0.00^{\mathrm{ab}}$ & $90.64 \pm 0.01^{\mathrm{a}}$ \\
\hline Total phenolic $(\mathrm{mg} \mathrm{GAE} / \mathrm{g})$ & $10.53 \pm 0.03^{\mathrm{c}}$ & $12.80 \pm 0.00^{\mathrm{bc}}$ & $14.97 \pm 0.01^{\mathrm{b}}$ & $16.40 \pm 0.02^{\mathrm{ab}}$ & $17.85 \pm 0.02^{\mathrm{a}}$ \\
\hline Total carotenoid $(\mathrm{mg} / \mathrm{kg})$ & $97.35 \pm 0.01^{\mathrm{c}}$ & $101.15 \pm 0.03^{\mathrm{bc}}$ & $109.58 \pm 0.02^{\mathrm{b}}$ & $115.62 \pm 0.01^{\mathrm{ab}}$ & $121.43 \pm 0.00^{\mathrm{a}}$ \\
\hline $\mathrm{IC}_{50}$ index $(\mathrm{mg} / \mathrm{ml})$ & $22.07 \pm 0.00^{\mathrm{a}}$ & $21.73 \pm 0.02^{\mathrm{ab}}$ & $20.45 \pm 0.00^{\mathrm{b}}$ & $19.80 \pm 0.00^{\mathrm{bc}}$ & $18.74 \pm 0.01^{\mathrm{c}}$ \\
\hline
\end{tabular}

Figures are the mean of three replications; Figures in row followed by the same letter/s are not differed significantly $(\alpha=P=0.05)$.

extraction time was ideal for oil extraction from Jatropha seed (26). The optimal extraction duration of $5 \mathrm{hrs}$ was adequate for the extraction of sunflower cotton and soybean seeds (27). Extraction time from 3.5 to $4.5 \mathrm{hrs}$ induced the highest soybean oil yield (28). Oil extraction ability was improved with $\mathrm{hr}$ increase in extraction time (9). Fractionation time acceleration induced an increased recovery and decreased iodine value (42). Chemical attributes of rambutan seed oil showed acid value (0.37\%), iodine value $(37.64 \%)$ and saponification value $(157.07 \mathrm{mg}$ $\mathrm{KOH} / \mathrm{g}$ ) (43). Comparing to TCVN 7597: 2013, the extracted rambutan seed oil had oxidative indicators within acceptable limits.

\section{Conclusion}

Rambutan (Nephelium lappaceum L.) seed is normally considered a waste during fruit processing. We have successfully examined different parameters such as seed powder size, the mixture of ethanol/ethyl acetate, solvent to solid ratio, extraction temperature and extraction time affecting recovery efficiency, chemical quality and antioxidant attributes of vegetable oil. Rambutan seed should be finely ground to medium particle size (35 mesh sieve), soaked with a fair ratio of ethanol/ethyl acetate $(3 / 1, \mathrm{v} / \mathrm{v})$ for 30 min, solvent/material ratio $(7 / 1, \mathrm{v} / \mathrm{w})$; extraction at medium temperature $\left(50{ }^{\circ} \mathrm{C}\right)$ in an appropriate duration (60 min). Rambutan seed oil obtained by this research may lead to its potential application as promising alternative edible oil to replace hydrogenated fat in specific foodstuffs as well as cosmetic patterns.

\section{Acknowledgements}

We acknowledge the financial support for the publication provided by Thu Dau Mot University, Binh Duong province, Vietnam.

\section{Authors' contributions}

Nguyen Phuoc Minh arranged the experiments and also wrote the manuscript.

\section{Conflict of interests}

The author strongly confirmed that this research was conducted with no conflict of interest.

\section{References}

1. Parcell J, Kojima Y, Roach A, Cain W. Global edible vegetable oil market trends. Biomed Journal of Scientific and Technical Research. https://doi.org/10.26717/BJSTR.2018.02.000680

2018;2:1-10.

2. Tayde S, Patnaik M, Bhagt SL, Renge VC. Epoxidation of vegetable oils: A review. International Journal of Advanced Engineering Technology. 2011;2:491-01

3. Bhuiya MMK, Rasul MG, Khan MMK, Ashwath N, Azad AK, Mofijur M. Optimization of oil extraction process from Australian native beauty leaf seed. (Calophyllum innophyllum). $7^{\text {th }}$ International Conference on Applied Energy ICAE 2015 Energy Procedia. 2015;75:56-61.

4. Gibbins RD, Aksoy HA, Ustun G. Enzyme-assisted aqueous extraction of safflower oil: optimization by response surface methodology. International Journal of Food Science and Technology. 2012;47:1055-62. https://doi.org/10.1111/j.13652621.2012.02940.x

5. Dawidowichz AL, Rado E, Wianowska D, Mardarowicz M Gawdzik J. Application of PLE for the determination of essential oil components from Thymus vulgaris L. Talanta. 2008; 76: 87884. https://doi.org/10.1016/j.talanta.2008.04.050

6. Takadas F and Doker O. Extraction method and solvent effect on safflower seed oil production. Chemical and Process Engineering Research. 2017;51:9-17. https://iiste.org/Journals/index.php/CPER/ article/view/36830/37871

7. Yusuf AK. A review of methods used for seed oil extraction. International Journal of Science and Research. 2018;7:233-38.

8. Dutta R, Sarkar U, Mukherjee A. Soxhlet extraction of Crotalaria juncea oil using cylindrical and annular packed beds. International Journal of Chemical Engineering and Applications. 2015;6:130-33. http://www.ijcea.org/vol6/466-H0017.pdf

9. Muzenda E, Kabuba J, Mdletye P, Belaid M. Optimization of process parameters for castor oil production. Proceedings of the World Congress on Engineering. 2012;3:4-6.

10. Sirisompong W, Jirapakkul W, Klinkesorn U. Response surface optimization and characteristics of rambutan (Nephelium lappaceum L.) kernel fat by hexane extraction. LWT-Food Science and Technology. 2011;44:1946-51. https://doi.org/10.1016/j.lwt.2011.04.011

11. Fila WA, Itam EH, Johnson JT, Odey MO, Effiong EE, Dasofunjo K, Ambo EE. Comparative proximate compositions of watermelon Citrullus lanatus, squash Cucurbita pepo L. and rambutan Nephelium lappaceum. International Journal of Science and Technology. 2013;2:81-88.

12. Mahmood K, Fazilah A, Yang TA, Sulaiman S, Kamilah H. Valorization of rambutan (Nephelium lappaceum) by-products: Food and non-food perspectives. International Food Research Journal. 2018; 25:890-02. http://www.ifrj.upm.edu.my/25\%20(03)\%202018/(2).pdf

13. Manaf YN, Marikkar JMN, Long K, Ghazali HM. Physicochemical characterization of the fat from red-skin rambutan (Nephelium lappaceum) seed. Journal of Oleo Science. 2013;62:335-43. https:// www.jstage.jst.go.jp/article/jos/62/6/62_335/_pdf

14. Solis-Fuentes JA, Camey-Ortiz G, Hernandez-Medel MR, PerezMendoza F, Duran-deBazua C. Composition, phase behavior and thermal stability of natural edible fat from rambutan (Nephelium lappaceum L.) seed. Bioresource Technology. 2010; 101: 799-03. https://doi.org/10.1016/j.biortech.2009.08.031 
15. Luma $\mathrm{KH}$ and Yang TA. Comparing the structural parameters of rambutan seed fat incorporated wholly and partially with cocoa butter. International Journal of Scientific and Engineering Research. 2016;7:921-28.

16. Issara U, Zzaman W, Yang TA. Rambutan seed fat as a potential source of cocoa butter substitute in confectionary product. International Food Research Journal. 2014;21:25-31. http://www.ifrj.upm.edu.my/21\%20(01)\%202014/3\%20IFRJ \%2021\%20(01)\%202014\%20Tajul\%20262.pdf

17. Zzaman W, Issara U, Febrianto NF, Yang TA. Fatty acid composition, rheological properties and crystal formation of rambutan fat and cocoa butter. International Food Research Journal. 2014;21:983-87. http://www.ifrj.upm.edu.my/21\%20(03)\%202014/25\%20IFR \%2021\%20(03)\%202014\%20Yang\%20650.pdf

18. Uraiwan $\mathrm{K}$ and Satirapipathkul C. The entrapment of vitamin $\mathrm{E}$ in nanostructured lipid carriers of rambutan seed fat for cosmeceutical uses. Key Engineering Materials. 2016;675-76:7780. https://doi.org/10.4028/www.scientific.net/KEM.675-676.77

19. Singleton VL and Rossi JAJR. Colorimetry of total phenolics with phosphomolybdicphosphotungstic acid reagents. American Journal of Enology and Viticulture. 1965;16:144-58.

20. Lucia MJC, Patrícia BG, Ronoel LOG, Sidney P, Pedro HFM, José LVC, Marília RN, Ana CLA, Carolina RAV, Semíramis RRR. Tota carotenoid content, $\alpha$-carotene and $\beta$-carotene, of landrace pumpkins (Cucurbita moschata Duch): A preliminary study. Food Research International. 2012;47:337-40. https://doi.org/10.1016/j.foodres.2011.07.040

21. Valentao P, Fernandes E, Carvalho F, Andrade PB, Seabra RM, Bastos ML. Antioxidant activity of Centarium erythraea infusion evidenced by its superoxide radical scavenging and xanthine oxidase inhibitory activity. Journal of Agriculture and Food Chemistry. 2001;49:3476-79. https://doi.org/10.1021/jf001145s

22. Park HS, Choi HK, Lee SJ, Park KW, Choi SG, Kim KH. Effect of mass transfer on the removal of caffeine from green tea by supercritical carbon dioxide. Journal Supercritical Fluids 2007;42:205-11. https://doi.org/10.1016/j.supflu.2007.03.002

23. Takeuchi TM, Pereira CG, Braga MEM, Marostica MR, Leal PF, Meireles MAA. Extracting bioactive compounds for food products-theory and applications. Boca Raton: CRC Press, 2009.

24. Olakunle MS, Ameh AO, Oyegoke T, Shehu HU. Effect of ethyl acetate, time and particle size on the kinetic modeling of the oleoresin extraction process. Journal of Engineering Sciences. 2020; 7: 15-23. https://doi.org/10.21272/jes.2020.7(2).f3

25. Saidi PP, Arya OP, Pradhan RC, Singh RS, Rai BN. Separation of oleoresin from ginger rhizome powder using green processing technologies. Journal of Food Process Engineering. 2014;38: 1745-60. https://doi.org/10.1111/jfpe.12127

26. Sayyar S, Abidin ZZ, Yunus R, Muhammad A. Extraction of oil from Jatropha seeds optimization and kinetics. American Journal of Applied Science. 2009;6:1-7. https://doi.org/10.3844/ ajassp.2009.1390.1395.

27. Abdulkarim A and Saady AM. Factors affecting the extraction process of oil-bearing flakes of sunflower, cotton and soybean seeds. Journal of Kerbala University. 2010;8:32-47.

28. Lawson O, Oyewumi A, Ologunagba F, Ojomo AO. Evaluation of the parameters affecting the solvent. ARPN Journal of Engineering and Applied Sciences. 2010;5:51-55.

29. Banat F, Pal P, Jwaied N, Al-Rabadi A. Extraction of olive oil from olive cake using soxhlet apparatus. American Journal of Oil and Chemical Technologies. 2013; 1: 1-8.

30. Mohd ACY, Manzurudin H, Norasikin O, Siti HMS, Liza MS Muhammad AAZ, Zuhaili I, Salman Z. Effect of particle size on the oil yield and catechin compound using accelerated solvent extraction. Jurnal Teknologi. 2013;60:21-25.

31. Mukhopadhyay M. Natural extracts using supercritical carbon dioxide. CRC Press, Boca Raton, 2000

32. Jadeja GC, Maheshwari RC, Naik SN. Extraction of natura insecticide azadirachtin from neem (Azadirachta indica A. juss) seed kernels using pressurized hot solvent. Journal of Supercritical Fluid. 2011;56:253-58. https://doi.org/10.1016/j.supflu.2011.01.004

33. Shittu SK, Mari HH, Dangora ND. Statistical model for solvent oil extraction from soybean (Glycine max (L.). Food Research. 2019;3:182-87. https://doi.org/10.26656/fr.2017.3(2).111

34. Oliveira RC, Guedes TA, Gimenes ML, Barros STD. Effect of process variables on the oil extraction from passion fruit seeds by conventional and non-conventional techniques. Acta Scientiarum Technology. 2014;36:87-91. https://doi.org/10.4025/actascitechnol.v36i1.15217

35. Ameh AO, Olakunle MS, Shehu HU, Oyegoke T. Kinetics of the extraction of oleoresin from ginger: Influence of particle size and extraction time effects. NIPES Journal of Science and Technology Research 2020;2:142-51. https://doi.org/10.37933/nipes/2.2.2020.14

36. Thi TNN, Xuan BN, Thi NHL. Green solvent extraction and quality characteristics of passion fruit seed oil (Passiflora edulis Sims var. edulis). Vietnam Journal of Agricultural Sciences. 2020;2:469-74. https://doi.org/10.31817/vjas.2019.2.4.03

37. Attah JC and Ibemesi JA. Solvent extraction of the oils of rubber, melon, pumpkin and oilbean seeds. Journal of American Oil Chemist's and Society. 1990; 67: 25-27.

38. Yusuf KA, Olaniyan AM, Atanda EO, Sulieman IA. Effects of heating temperature and seed condition on the yield and quality of mechanically expressed groundnut oil. International Journal of Technology Enhancements and Emerging Engineering Research. 2014; 2: 73-78.

39. Ebewele RO, Iyayi AF, Hymore FK. Considerations of the extraction process and potential technical applications of Nigerian rubber seed oil. International Journal of the Physical Sciences. 2010; 5: 826-31.

40. Momoh OJ, Okafor VN, Obada DO. Mathematical modeling of the solvent extraction of palm kernel oil from palm kernel. Palestine Technical University Research Journal. 2015; 3: 23-29.

41. Marta MC, Diana D, Guillermo SM. Influence of extraction with ethanol or ethyl acetate on the yield of lycopene, $\beta$-carotene phytoene and phytofluene from tomato peel powder. Eur Food Res Technol. 2007; 224: 567-71. https://doi.org/ 10.1007/s00217 006-0335-8

42. Busakorn M, Kriskamol NJ, Shingo M, Utai K. Solven fractionation of rambutan (Nephelium lappaceum L.) kernel fa for production of non-hydrogenated solid fat: Influence of time and solvent type. Journal of King Saud University-Science. 2017;29:32-46. https://doi.org/10.1016/j.jksus.2016.08.004

43. Serida NH, Nazaruddin R, Mamot S. Physicochemical and nutritional composition of rambutan anak sekolah (Nephelium lap paceum L.) seed and seed oil. Pakistan Journal of Nutrition. 2012;11:1073-77. https://doi.org/10.3923/pjn.2012.1073.1077

\section{Additional information}

Peer review information: Plant Science Today thanks Sectional Editor and the other anonymous reviewers for their contribution to the peer review of this work.

Reprints and permissions information is available at https://horizonepublishing.com/journals/index.php/PST/open_access_policy

Publisher's Note: Horizon e-Publishing Group remains neutral with regard to jurisdictional claims in published maps and institutional affiliations.

To cite this article: Minh N P. Parameters affecting oil extraction from rambutan (Nephelium lappaceum L.) seed. Plant Science Today. 2021;8(4):867-872. https://doi.org/10.14719/pst.2021.8.4.1274

Plant Science Today, published by Horizon e-Publishing Group, is covered by Scopus, Web of Science, BIOSIS Previews, Clarivate Analytics, etc. See https://horizonepublishing.com/journals/index.php/PST/indexing_abstracting 